\title{
The Effect of Different Solutions on the Bond Strength of Soft Lining Materials to Acrylic Resin
}

\author{
Nuran YANIKOĞTLU and Saip DENIZZOĞLU \\ Department of Prosthodontics, Faculty of Dentistry, Atatürk University, Erzurum, Turkey \\ Corresponding author, Nuran Yanikoğlu E-mail:ndinckal@atauni.edu.tr; nyanikoglu@yahoo.com; saip@atauni.edu.tr
}

Received April 11, 2005/Accepted November 21, 2005

\begin{abstract}
In this study, we investigated the effect of different solutions - coffee, tea, Turkish coffee, artificial saliva, mouthwash, denture cleanser, and distilled water - on the bond strength of soft lining materials (one acrylic- and three silicone-based) to acrylic resin. Acrylic specimens $(40 \times 10 \times 10 \mathrm{~mm})$ were prepared for the bond strength test. The specimens were stored in different solutions and tested after 24 hours, seven days, and 30 days.

Using analysis of variance, the bond strength of soft lining materials to acrylic resin was found to be related to the type of material, storage time, and storage solution. Visco-gel had the lowest bond strength to cured acrylic resin, where its strength ranged from $0.149 \mathrm{MPa}$ to $0.784 \mathrm{MPa}$. The bond strength of Visco-gel was also found to increase with time.

Molloplast-B and Ufi Gel P demonstrated better bond strength than Visco-gel and Mollosil.
\end{abstract}

Key words: Soft lining materials, Bond strength, Denture cleanser

\section{INTRODUCTION}

Soft lining materials are used to help distribute a functional load evenly on a denture-bearing area so as to avoid local stress concentrations, and thereby improve denture retention by engaging undercuts ${ }^{1)}$. These materials are used as long-term denture liners for the management of atrophied mucosa or traumatic ulceration and for obturators after maxillafacial surgery ${ }^{2}$. The materials mentioned can be classified as provisional or definitive. Then, depending on their chemical composition - silicone rubber or acrylic resin, they can either be chemically or heat polymerized ${ }^{3,4)}$

The key requirements for long-term, resilient liners are namely permanent resiliency, high dimensional stability, good adhesion to denture base, adequate tear resistance, and compatibility with oral tissue $^{5,6)}$. One of the major serious problems with soft denture liners is adhesion failure between the soft liner material and denture base ${ }^{7-11)}$. Bond failures also create a potential surface for bacterial growth, plaque accumulation, and calculus formation ${ }^{11)}$. Bonding of resilient lining materials to acrylic resin has been evaluated by several researchers using lap shear, butt tensile and peel tests ${ }^{6,12-15)}$, whereby in vitro tensile test was found to be an effective method in determining bond strength ${ }^{11}$.

The purpose of this study was to evaluate the effect of different solutions (coffee, tea, Turkish coffee, artificial saliva, denture cleanser, mouthwash, and distilled water) on the bond strength of soft lining materials to acrylic resin.

\section{MATERIALS AND METHODS}

Blocks of acrylic resin (40 $\mathrm{mm}$ in length $\times 10 \mathrm{~mm}$ in height $\times 10 \mathrm{~mm}$ in thickness) were prepared. Individual acrylic samples were prepared by investing brass dies with a $3-\mathrm{mm}$ thick spacer in a denture flask.

A lining less than $1.5 \mathrm{~mm}$ thick would appear to be clinically unacceptable because such thin linings would not have sufficient resilience to render the required cushioning effect. To ensure successful use of soft liner materials with dentures, processing techniques must be carefully applied, soft lining material must be adequately thick $(2-3 \mathrm{~mm})$, and denture base must be strengthened if it is weakened by lining presence $^{16-18)}$

Two acrylic specimens (QC-20, heat polymerized, De Trey Weybridge, Surrey, England) were trimmed, and the surfaces to be bonded were abraded with silicone carbide paper (\#600, 3M Dental, Minn.) and treated according to the manufacturer's instructions for each soft denture liner. Acrylic resin blocks were placed back into the molds, and the soft denture liners packed into the space provided by the brass spacer and cured in accordance to the manufacturers' instructions. Bonding agents supplied by the manufacturers were used on the acrylic specimens. Only Visco-gel samples were prepared without any bonding agent. As shown in Table 1, four soft denture liners were used in this study. After polymerization was completed, the samples were removed from the flask.

For each soft lining material, 63 specimens were prepared: three specimens for each test solution for each storage period. Therefore, a total of 252 speci- 
Table 1 List of materials and manufacturers

\begin{tabular}{clcc}
\hline Material & \multicolumn{1}{c}{ Type } & Lot Number & Company \\
\hline Molloplast-B & High temperature vulcanized & 030942 & Detax, GmbH a Co KG, \\
& Silicone-based & $2005-09$ & Ettlingen, Germany \\
Mollosil & Cold-cured silicone-based & 030701 & Detax, GmbH a Co KG, \\
& & $2006-07$ & Ettlingen, Germany \\
Ufi Gel P & Cold-cured silicone-based & 330509 & Voco, Cuxhaven, Germany \\
& & $2005-03$ & Dentsply, De Trey GmbH, \\
Visco-gel & Mouth temperature cured & 0309001608 & Konstanz, Germany \\
& Acrylic resin & $2005-05$ & \\
\hline
\end{tabular}

mens were prepared for the four soft lining materials tested in this study.

One hundred and eighty specimens were immersed in different solutions (coffee, tea, Turkish coffee, artificial saliva, and distilled water) at a constant temperature of $37 \pm 1{ }^{\circ} \mathrm{C}$ for 24 hours, seven days, and 30 days.

To prepare the coffee solution, $15 \mathrm{~g}$ of coffee powder (Nescafe Classic, Nestlé, Société des Produits, SPN, Switzerland) was poured into $500 \mathrm{ml}$ of boiling distilled water. The tea solution was prepared by immersing five prefabricated doses of tea (Lipton, Yellow Label, Çorlu, Turkey) into $500 \mathrm{ml}$ of boiling water for 10 minutes.

Turkish coffee was prepared by adding $5-7 \mathrm{~g}$ of a commercial brand (Kurukahveci Mehmet Efendi, TS 3117, Y Dudullu, Istanbul) to $65 \mathrm{ml}$ of cold distilled water, and then boiled for a few minutes.

Artificial saliva was prepared with the following composition $^{19)}$ : $\mathrm{NaCl}, 0.400 \mathrm{~g} ; \mathrm{KCl}, 0.400$ g; $\mathrm{CaCl}_{2} \mathrm{H}_{2} \mathrm{O}$, 0.795 g; $\mathrm{NaH}_{2} \mathrm{PO}_{4}, 0.78 \mathrm{~g} ; \mathrm{Na}_{2} \mathrm{~S} .9 \mathrm{H}_{2} \mathrm{O}, 0.005 \mathrm{~g}$; urea 1 $\mathrm{g}$; distilled water, $1000 \mathrm{ml}(\mathrm{pH}=5.5)$.

Thirty-six specimens were immersed in a fresh solution of denture cleanser (Fitty Dent Cleansing Tablets, Fittydent International GmbH A-7423, Pinkafeld, Austria) at room temperature for eight hours, and then washed thoroughly with tap and distilled water. Following which, they were immersed in distilled water at $37^{\circ} \mathrm{C}$ for the remainder of the 24hour period. The denture cleanser solution was changed weekly.

Thirty-six specimens prepared from each test material were stored in $20 \mathrm{ml}$ of a mouthwash (Andorex, Kim Pa, İstanbul, Turkey) for one, six, and 12 hours. The 12-hour immersion period was reported to be the equivalent time of a two-minute daily mouthwash for a whole year ${ }^{20)}$.

Distilled water was used as a control group. During the test period, all staining solutions were changed once a week.

For tensile bond strength measurement, samples were placed under tension inside a Instron 3344 machine (Instron Corp., 100 Royall St., Canton, Ma.,
02021, USA) using a cross-head speed of $2 \mathrm{~cm} / \mathrm{mm}$ until failure occurred. Bond strength was calculated by dividing stress at failure by the cross-sectional area of the sample. Means and standard deviations were determined for all materials. Bond strengths were then compared using one-way analysis of variance and LSD (least significant difference) multiple range test.

\section{RESULTS}

According to the variance analysis, the type of material, storage time, and storage solution had statistically significant effects on the bond strength of soft lining materials $(p<0.001)$.

The mean values of the bond strength for all materials after stored in the different solutions and distilled water are graphically displayed in Fig. 1 and 2. Lowest bond strength was observed with Viscogel at $0.149 \mathrm{MPa}$ in coffee after seven days. Highest bond strength, on the other hand, was observed with bonded Molloplast-B at $1.616 \mathrm{MPa}$ in distilled water after seven days. The lowest bond strength of Molloplast-B at $0.639 \mathrm{MPa}$ was observed in denture cleanser after seven days. Based on the results of this study, it could be suggested that Molloplast-B, Mollosil and Ufi Gel P failed adhesively while Viscogel failed cohesively.

At the end of 30 days, Mollosil registered its lowest bond strength at $0.376 \mathrm{MPa}$ in coffee, and Ufi Gel $\mathrm{P}$ at $0.574 \mathrm{MPa}$ in Turkish coffee.

In the mouth wash, Visco gel demonstrated lower bond strengths than the other materials, whereby its bond strength ranged from $0.293 \mathrm{MPa}$ to $0.215 \mathrm{MPa}$., and the lowest bond strength of Mollosil at $0.380 \mathrm{MPa}$ was observed after 6 hours. At the end of 12 hours, Ufi Gel $\mathrm{P}$ was showed the lowest bond strength at $0.634 \mathrm{MPa}$, Molloplast-B at $0.830 \mathrm{MPa}$ in mouth wash. In general, all materials showed low bond strength in mouthwash.

According to the LSD test:

- The materials showed the same values in ordinary coffee, Turkish coffee and tea. 

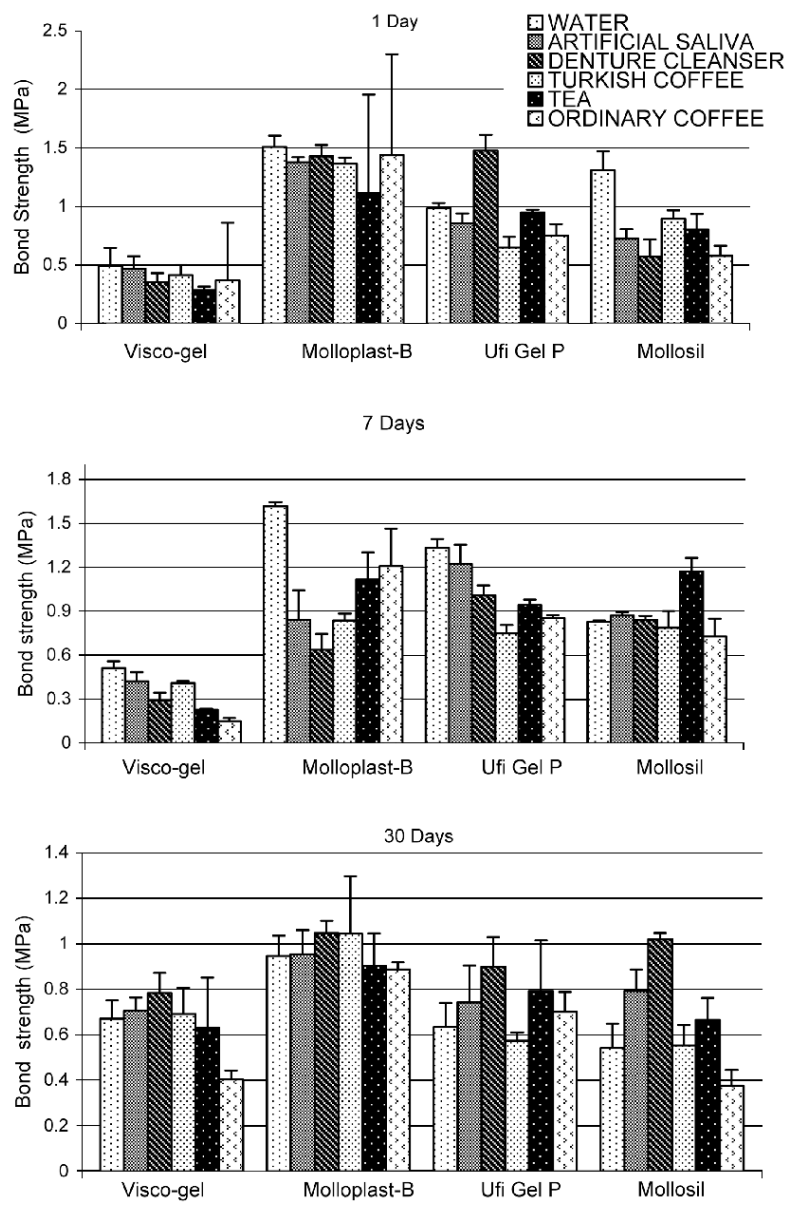

Fig. 1 Bond strengths (MPa) of soft lining materials in different storage solutions after 1,7 and 30 days.

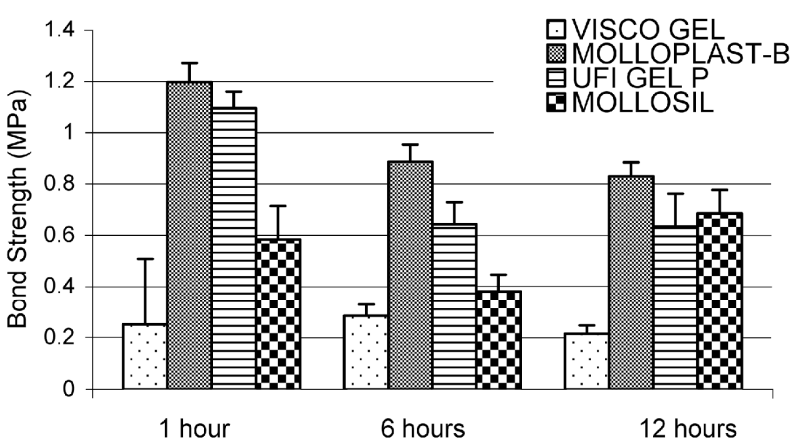

Fig. 2 Bond strengths (MPa) of soft lining materials in Mouth wash.

- There were no differences in the bonding resistance of samples kept in distilled water and denture cleanser.

- There was a similarity in the bonding resistance of samples kept in Turkish coffee and ordinary coffee.

- Bond strengths were significantly different between storage solution and storage time.

\section{DISCUSSION}

In this study, the bond strength of one acrylic-based and three silicone-based soft lining materials to acrylic resin were determined by a tensile test. Some studies have reported on bond strength between soft lining materials and acrylic resins, and when separation took place the localized area became unhygienic and non-functional ${ }^{11,16)}$.

Heat-cured silicone-based Molloplast-B showed a higher bond strength than the other silicone-based liners, and Molloplast-B - like the other siliconebased liners - also required a bonding agent for adhesion to the cured acrylic resin. According to Aydin et $a l{ }^{21)}$ and Yanikoğlu et $a{ }^{22)}$, heat-cured silicone-based Molloplast-B had the highest tensile strength and best filling capacity among the soft lining materials. Further, according to Wright $^{6)}$, this higher bond strength was attributable to improved adhesive bonding systems used with silicone-based soft liners, which usually contain a silicone polymer in a volatile solvent that is able to penetrate the acrylic resin. Nevertheless, in another study, Açıkgöz et $a l .{ }^{15)}$ suggested that silicone-based Ufi Gel $\mathrm{P}$ exhibited the greatest bond strength.

The powder of Visco-gel is a polyethyl methacrylate, and no bonding agents are needed to achieve a bond with acrylic resin ${ }^{11)}$. Visco-gel material failed cohesively, which implied that the tensile strength of the soft liner material was lower than that of the bond strength to the acrylic specimens ${ }^{11,22)}$. The high interfacial strength in this case could be attributed to the mechanical bonding between Visco-gel and the acrylic specimen. Mechanical bonding occurred due to the wet sandpaper treatment of the acrylic resin surface, thus leading to increased surface roughness and mechanical retention ${ }^{3,11}$.

High sorption and solubility of soft denture liners are associated with distortion, hardening, and debonding of liners from denture bases ${ }^{8)}$. Therefore, sorption and solubility properties are important indicators to a liner's longevity ${ }^{23)}$. Kawano et al. ${ }^{11)}$ stated that denture liners demonstrated the best bond strength when they were first bonded to a new acrylic denture base. However, it must be pointed out that bond strength would be comparatively inferior if old dentures are relined. This is because the acrylic denture base might already be contaminated by microorganisms and other materials absorbed into the denture base from food or cleansing agents.

The present study showed that tensile bond strength increased with time for Visco-gel (in distilled water: $0.494 \mathrm{MPa}$ after one day, $0.670 \mathrm{MPa}$ after 30 days). This could have occurred because of the leaching out of the plasticizer, which in turn resulted in increased stiffness ${ }^{24)}$. The deterioration rate of Visco-gel is related to ethanol elution. The absorption or loss of soluble components may cause 
failures in bond strength between the soft liner and acrylic resin, thus causing mechanical bonding and chemical adhesion to take form between the soft liner material and acrylic resin ${ }^{3)}$.

In contrast, the bond strengths of Molloplast-B, Mollosil, and Ufi Gel $\mathrm{P}$ decreased after storage in distilled water for 30 days. This finding agreed with those of earlier reports by Amin et $a l .{ }^{24)}$ and Polyzois $^{25)}$, which stated that water storage reduced the bond strength of resilient liners ${ }^{25)}$. Water absorbed by a denture liner material has direct and indirect effects on its bonding to acrylic resins. The water absorbed may indirectly decrease the bond strength by causing plasticizer to leach out from the liner. Diminished plasticizer content will increase stiffness and reduce the cushioning effect of the liner material $^{14,15)}$.

Wright ${ }^{6)}$ indicated that Molloplast-B did not seem to be affected by immersion in water, whereas the bond strength of a natural rubber material was weakened since its adhesion was reduced following immersion in water.

Aydin et $a l .{ }^{21)}$ stated that the bonding strength of soft liners behaved differently. After aging treatment and storage in water, the bond strength of Ufi Gel $\mathrm{P}$ decreased but there was barely any change for Molloplast-B. They further recommended that among high temperature vulcanized (HTV) silicone, room temperature vulcanized (RTV) and chemicalcured soft liners, HTV material should be the preferred choice.

Craig $^{2)}$ suggested that storage in water did not affect the bonding of denture liners to PMMA. By roughening the PMMA surface before bonding, it would approximately double the adhesion values of the resilient liners.

The findings of the present study did not agree with those of Wright $^{6)}$, Aydin et al. ${ }^{21)}$ and Craig ${ }^{2)}$. These discrepancies in findings might be a result of different parameters used in each study, namely the acrylic resin, storage time, storage solution, and cross-head speed of the testing machine.

Amin et $a l .{ }^{12)}$ measured the bond strength of four soft denture liners using tensile, shear, compression, and peel tests. They concluded that roughening the acrylic base before applying the lining material had a weakening effect on bonding. While the bond strengths of acrylic and silicone soft lining materials to acrylic resin are tested by tensile stress, this test is not completely valid and applicable to dental restorations because the forces they encounter are more closely related to shear and tear. The in vitro tensile test was found to be effective in evaluating bond strength ${ }^{11}$. The results of this study indicated that the failure force for Mollosil was $0.542 \mathrm{MPa}$ and that of Visco-gel was $0.670 \mathrm{MPa}$ at the end of 30 days. As previously reported, soft denture lining materials with adequate bond strength are acceptable for clinical use $\mathrm{e}^{14,21)}$.

The liner material must remain stable in the salivary oral environment ${ }^{10)}$. An ideal, processed soft liner should have no soluble components and low water sorption ${ }^{10,13)}$. During immersion in different solutions, plasticizer and other soluble components are leached out and water or saliva is absorbed by the polymer ${ }^{26)}$. Acrylic resin permanent soft lining materials have higher sorption values than silicone soft lining materials ${ }^{27)}$. High sorption and solubility of soft denture liners are associated with distortion, hardening, and debonding of liners from acrylic denture bases ${ }^{8)}$. Lower uptake in artificial saliva can be explained in terms of the ionic impurities in the polymer $^{28)}$. In the present study, Visco-gel showed lower bond strength than Molloplast-B in artificial saliva. In a previous study on the adhesion properties of resilient lining materials to a visible light cured (VLC) acrylic resin, it was shown that adhesive characteristics depended on a variety of factors: chemical properties, physical properties, and mode of polymerization of the resilient lining material, and the bonding agent used ${ }^{10,25)}$. In an investigation by Polyzois $^{25)}$, all lining materials were acceptable for clinical use but water storage reduced their bond strength to VLC acrylic resins.

Solutions used for denture cleaning can be divided according to their chemical composition: alkaline peroxides, alkaline hypochlorites, acids, disinfectants, and enzymes ${ }^{29,30)}$. Enzymatic solutions are more effective in preventing microbial invasion and plaque formation ${ }^{31,32)}$. In the present study, a similarity was found between the bond strength of samples kept in distilled water and that in denture cleanser $(0.863 \mathrm{MPa})$. This finding agreed with the results of an earlier report by Rodrigues Garcia et $a l .^{33)}$. They stated that enzymatic denture cleansers, when compared with water, did not cause significant changes in tensile bond strength. In the present study, the denture cleanser used contained sodium bicarbonate and ethylenediamin. It was probable that the higher ionic concentration (potassium and sodium) of denture cleanser - compared to water - led to a higher release of soluble components. In other words, chemical solutions - such as denture cleaner can cause significant deterioration because they can cause loss of soluble components and plasticizers, or absorption of water or saliva by the resilient lining materials $^{26,33,34)}$. Loss of plasticizer can alter the bonding surface or the viscoelastic properties of resilient materials, causing the latter to become brittle, hence changing their bond strength properties ${ }^{25)}$.

Use of mouthwash has become increasingly popu$\operatorname{lar}^{35)}$. Besides from being an effective caries and gingivitis control method and a topical relief measure for oral lesions, people also tend to use mouthwash for social and cosmetic reasons ${ }^{35-38)}$. In this study, soft denture materials placed in mouthwash showed 
low bond strength (mean value: $0.641 \mathrm{MPa}$ ) - which implied that the chemical composition of mouthwash might significantly affect bond strength. Gurgan et $a l{ }^{39)}$ suggested that alcohol-containing and alcoholfree mouthwash affected the hardness of some restorative materials. Gürdal et $a l^{40)}$, on the other hand, found that mouthwash with varying $\mathrm{pH}$ values and alcohol contents had no effect on the microhardness and color stability of esthetic restorative materials which were tested. Since no other literature could be found concerning the effect of mouthwash, discussion on the bond strength of soft lining materials when treated by mouthwash in vitro is not possible.

\section{REFERENCES}

1) Heartwell CM, Rahn AO. Syllabus of complete dentures, 4th ed, Lea \& Febiger Inc, Philadelphia, 1986, pp.423-456.

2) Craig RG. Restorative dental materials, 7th ed, CV Mosby Co, St. Louis, 1986, pp.496-498.

3) Sinobad D, Murphy WM, Huggett R, Brooks S. Bond strength and rupture properties of some soft denture liners. J Oral Rehabil 1992; 19: 151-160.

4) Wright PS. Composition and properties of soft lining materials for acrylic dentures. J Dent 1981; 9: 210-223.

5) Qudah S, Harrison A, Huggett R. Soft lining materials in prosthetic dentistry: $A$ review. Int $J$ Prosthodont 1990; 3: 477-483.

6) Wright PS. Characterization of adhesion of soft denture liners to poly (methyl methacrylate). J Dent Res 1982; 61: 1002-1005.

7) Sauve JL. Clinical evaluation of silastic 390 as a lining material for dentures. J Prosthet Dent 1966; 16: 650660.

8) Kawano F, Dootz ER, Koran A, Craig RG. Sorption and solubility of 12 soft denture liners. J Prosthet Dent 1994; 72: 393-398.

9) Waters MG, Jagger RG, Winter RW. Water absorption of (RTV) silicone denture soft lining material. J Dent 1996; 24: 105-108.

10) Emmer TJ Jr, Emer TJ Sr, Vaidynathan J, Vaidynathan TK. Bond strength of permanent soft denture liners bonded to the denture base. J Prosthet Dent 1995; 74: 595-601.

11) Kawano F, Dootz ER, Koran A. Comparison of bond strength of six soft denture liners to denture base resin. J Prosthet Dent 1992; 68: 368-371.

12) Amin WM, Fletcher AM, Ritchi GM. The nature of the interface between polymethyl methacrylate denture base materials and soft denture liners. J Dent 1981; 9: 336-346.

13) McMorsie R, King GE. Evaluation of primers used for bonding silicone to denture base materials. J Prosthet Dent 1989; 61: 636-639.

14) Khan Z, Martin J, Collard S. Adhesion characteristics of visible light-cured denture base materials bonded to resilient lining materials. J Prosthet Dent 1989; 62: 196200.
15) Açıkgöz O, Ceylan G, Dinçkal N. Yumuşak astar maddelerinin Poly (Methylmethacrylate) (PMMA) esash kaide maddesine tutunma güçlerinin incelenmesi [Investigation of bond strength of soft denture liners bonded to the Poly (Methylmethacrylate) (PMMA) denture base materials]. Atatürk Univ Diş Hek Fak Derg 1997; 7(1): 57-60.

16) Wright PS. A three year longitudinal study of denture soft lining materials in clinical use. Clin Mater 1986; 1: 281-291.

17) Kawano F, Tada N, Nagao K, Matsumoto N. The influence of soft lining materials on pressure distribution. J Prosthet Dent 1991; 65: 567-575.

18) Kazanji MNM, Watkinson AC. Influence of thickness, boxing and storage on the softness of resilient denture lining materials. J Prosthet Dent 1988; 59: 677-680.

19) Fusuyama $T$, Katayori $T$, Nomoto $S$. Corrosion and microhardness. J Dent Res 1963; 42: 1183.

20) Raptis CN, Powers JM, Fan PL, Yu R. Staining of composite resins by cigarette smoke. J Oral Rehabil 1982; 9: 367-371.

21) Aydın AK, Terzioğlu H, Akinay AE, Ulubayram K, Hasirci N. Bond strength and failure analysis of lining materials to denture resin. Dent Mater 1999; 15(3): 211218.

22) Yanıkoğlu ND, Denizoğlu S. An investigation of the tear energy of five soft lining materials. Dent Mater J 2003; 22(4): 444-451.

23) Yanıkoğlu ND, DuymuşZY. Comparative study of water sorption and solubility of soft lining materials in the different solutions. Dent Mater J 2004; 23(2): 233-239.

24) Amin WM, Fletcher AM, Ritchie GM. The nature of the interface between polymethylmethacrylate denture base materials and soft lining materials. J Dent 1981; 9: 336-346.

25) Polyzois GL. Adhesion properties of resilient lining material bonded to light-cured denture resins. J Prosthet Dent 1992; 68: 854-858.

26) Jones DW, Hall GC, Stutow EJ, Langman MF, Robertson KN. Chemical and molecular weight analyses of prosthodontic soft polymers. J Dent Res 1991; 70: 874879 .

27) El-hadary A, Drummond JL. Comparative study of water sorption, solubility, and tensile bond strength of two soft lining materials. J Prosthet Dent 2000; 83: 356-361.

28) Kazanji MNM, Watkinson AC. Soft lining materials: Their absorption and solubility in artificial saliva. $\mathrm{Br}$ Dent J 1988; 165: 91.

29) Lombardi T, Budtz-jorgensen E. Treatment of dentureinduced stomatitis: A review. Eur J Prosthodont Restor Dent 1993; 2: 17-22.

30) Budtz-jorgensen E. Materials and methods for cleaning dentures. J Prosthet Dent 1979; 42: 619-623.

31) Omdan PA. The effectiveness of an enzyme-containing denture cleanser. Quintessence Int 1992; 23: 187-190.

32) Minagi S, Tsunoda T, Yoshida K, Tsuru H. Objective testing of the efficiency of denture-cleansing agents. J Prosthet Dent 1987; 58: 595-598. 
33) Rodriques Garcia RCM, Leon BLT, Oliveira VBB, Del Bel Cury AA. Effect of a denture cleanser on weight, surface roughness, and tensile bond strength of two resilient denture liners. J Prosthet Dent 2003; 89: 489494.

34) Braden M, Wright PS. Water absorption and water solubility of soft lining materials for acrylic dentures. J Dent Res 1983; 62: 764-768.

35) Gagari E, Kabani S. Adverse effects of mouthwash use: A review. Oral Surgery Oral Medicine Oral Pathology Oral Radiology and Endodontics 1995; 80: 432439.

36) Winn DM, Blot WJ, McLaughlin JK, Austin DF, Greenberg RS, Preston-Martin S, Schoenberg JB, Fraumeni JF. Mouthwash use and oral conditions in the risk of oral and pharyngeal cancer. Cancer Research 1991; 51: 3044-3047.

37) Winn DM. Diet and nutrition in the etiology of cancer. Am J Clinic Nutri 1995; 61: 437S.

38) Penugonda B, Settembrini L, Scherer W, Hittellman E, Strassler H. Alcohol-containing mouthwashes: Effect on composite hardness. J Clin Dent 1994; 5: 60-62.

39) Gürgan S, Öner A, Köprülü H. In vitro effects of alcohol-containing and alcohol free mouth rinses on microhardness of some restorative materials. J Oral Rehabil 1997; 24: 244.

40) Gürdal P, Akdeniz BG, Şen BH. The effects of mouth rinses on microhardness and color stability of esthetic restorative materials. J Oral Rehabil 2002; 29(9): 895901. 